\title{
Large Cell Neuroendocrine Carcinoma (LCNEC) of the Colon Arising from a Tubulovillous Adenoma: A Case Report and Literature Review*
}

\author{
Jonathan L Dameworth ${ }^{1}$, Luc Colburn², Daniel Mistrot ${ }^{1}$, M Frances Hahn ${ }^{3}$, Raymond Shamos ${ }^{1}$, \\ David Row ${ }^{1}$
}

Corresponding author:

Jonathan L Dameworth, MD

St. Joseph's Hospital and Medical Center Department of Surgery

350 W Thomas Rd. Phoenix, AZ 85013

Office (602) 406-6540

Fax (602) 294-5644

E-mail: jonathandameworth@creighton.edu

${ }^{*}$ A version of this research was presented at the American Society of Colon and Rectal Surgeons Annual Scientific Meeting. June, 2019. Cleveland, OH, USA.

\section{Abbreviations:}

LCNEC - Large Cell Neuroendocrine Carcinoma;

NET - neuroendocrine tumors:

AC - adenocarcinomas;

NEC - neuroendocrine carcinoma;

SCNEC - small cell neuroendocrine carcinoma;

LOH - loss of heterozygosity;
'Department of Surgery, St. Joseph's Hospital and Medical Center, Phoenix, AZ ${ }^{3}$ Creighton University School of Medicine, Phoenix Regional Campus, Phoenix, AZ ${ }^{2}$ Department of Pathology, St. Joseph's Hospital and Medical Center, Phoenix, AZ

\section{ABSTRACT}

A 66-year-old man was found to have a $4 \mathrm{~cm}$ mass in the distal transverse colon that was biopsied on a diagnostic colonoscopy performed for occult anemia. Pathology showed incomplete removal of a tubulovillous adenoma with high-grade dysplasia. The patient underwent surgical resection, with final pathology demonstrating two $5 \mathrm{~mm}$ foci of large cell neuroendocrine carcinoma (LCNEC) within a background of tubulovillous adenoma, and 1 of 8 positive lymph nodes. Poorly-differentiated neuroendocrine tumors (NET) are termed neuroendocrine carcinoma (NEC), and are extremely rare. Colorectal LCNEC have been identified in synchronicity or association with adenomas and adenocarcinomas (AC). There are several theories that attempt to explain the pathogenesis of colorectal tumors with concurrent neuroendocrine and adenomatous pathology: (1) mixed tumors are a neuroendocrine phenotype of dedifferentiated adenocarcinoma; (2) these tumors originate from a common multipotent stem cell then simultaneously differentiate into glandular or neuroendocrine lineages; or, (3) a common genetic alteration predisposes an individual to the development of both tumor types. More work is needed to delineate the true pathogenesis of colorectal tumors with concurrent neuroendocrine and adenomatous pathology. There are no agreed-upon management guidelines for colorectal NEC, although given its highly aggressive nature, standard oncologic resection and adjuvant platinum-based chemotherapy are generally recommended for patients with resectable disease.

Key words: large cell neuroendocrine carcinoma, neuroendocrine tumor, colon cancer, colon adenoma

\section{CASE REPORT}

A 66-year-old man was found to have a $4 \mathrm{~cm}$ mass in the distal transverse Received: 04.08.2019 Accepted: 20.08 .2019 colon that was biopsied on a diagnostic colonoscopy performed for occult anemia. Pathology showed incomplete removal of a tubulovillous adenoma with high-grade dysplasia. He was referred to surgery and subsequently underwent partial colectomy. Pathology of the resected colon showed two 5 
$\mathrm{mm}$ foci of large cell neuroendocrine carcinoma (LCNEC) within a background of tubulovillous adenoma (fig. 1). The LCNEC was poorly-differentiated (G3) with invasion into the submucosa (T1) and 1 of 8 lymph nodes were involved(N1). Lymphovascular invasion was present. Preoperative imaging was not available; however, a post-operative staging $\mathrm{CT}$ did not show any evidence of metastatic disease. The patient was discussed at multidisciplinary tumor board. Given his pathology, he was taken back for the purposes of formal oncologic resection and increasing lymph node yield. Seven additional nodes were removed, all negative for malignancy. Adjuvant chemotherapy with cisplatin and etoposide was initiated six weeks after his second operation, and he ultimately completed 5 out of 6 cycles. He was advised to continue close follow-up for the first 3 years. Recommended surveillance consisted of history and physical examination every 3-6 months, annual CT imaging of the chest, abdomen, and pelvis, and trending of serum chromogranin A levels. His initial annual postoperative surveillance colonoscopy was unremarkable and demonstrated a patent colo-colonic anastomosis.

\section{DISCUSSION}

Neuroendocrine tumors (NET) are a heterogenous group of neoplasms arising from neuroectodermal cells. The World Health Organization (WHO) divides NET into well- and poorly-differentiated classifications. Well-differentiated NET include low- and mid-grade (G1 and $\mathrm{G} 2$ ) tumors, whereas poorly-differentiated NET (high-grade, or G3) are termed neuroendocrine carcinoma (NEC) (1). There are small cell (SCNEC) and large cell (LCNEC) types.The incidence of NET is rare, with roughly 5 cases per 100,000 in the general population. NET in the gastrointestinal tract account for $2 \%$ of $\mathrm{Gl}$ malignancies, with the majority being well- to moderately-differentiated (2).

NEC are extremely rare and represent less than $1 \%$ of all colorectal malignancies (3). Vascular, lymphatic, and perineural invasion, as well as lymph node metastases, are often found at diagnosis. In the case of metastatic disease associated with NEC, platinumbased chemotherapy is generally indicated (4). The majority of metastases occur to the liver and lungs, however, there have been reports of LCNEC presenting with peritoneal carcinomatosis (5). Generally, most NET have a better prognosis than conventional adenocarcinomas, however, colorectal NEC is a highly-malignant subgroup with a very poor prognosis (median survival 4-16 months and 5-year overall survival of 15-20\%) $(6,8)$. The treatment of choice remains formal oncologic surgical resection for all suitable patients.

Although extremely rare, colorectal LCNEC have been identified in synchronicity or association with adenomas and adenocarcinomas (AC) of the colon, rectum, and throughout the GI tract (7-10). The first classification system for tumors composed of both AC and NET was proposed in 1987 by Lewin in which neoplasms were divided into three categories: combined, collision, and amphicrine tumors. Combined and collision neoplasms consist of distinct components, either being intimately intermingled, or having separable components, respectively. Amphicrine lesions are those with cells having a mixed AC/NET phenotype (21). A review of the current literature shows that this is an exceedingly rare phenomenon and most reported
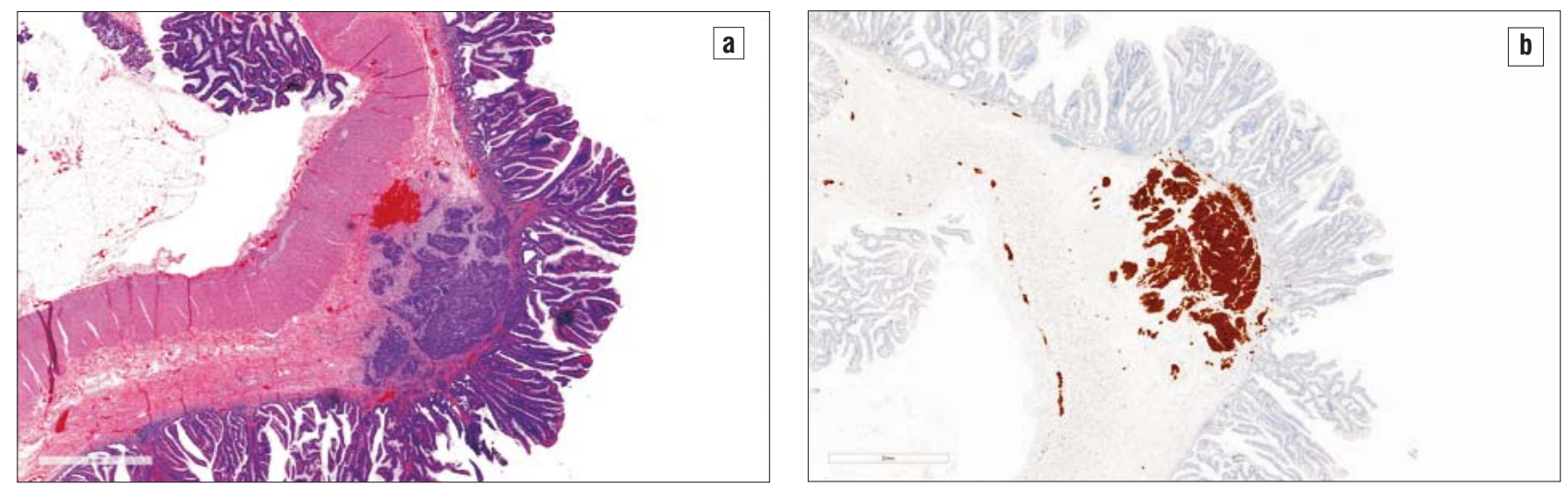

Figure 1 - Histologic appearance of tubulovillous adenoma and large cell neuroendocrine carcinoma. a) Low-power microscopy of a hematoxylin-eosin (H\&E) section demonstrates involvement of submucosa by nests and sheets of neoplastic cells. Higher magnification (not shown) demonstrates neoplastic cells with vesicular chromatin and prominent nucleoli; no gland differentiation seen. b) Synaptophysin (neuroendocrine marker) immunohistochemical stain. There is strong positive staining of the neoplastic cells, confirming neuroendocrine differentiation. 
Table 1 - PubMed literature search for case reports of neuroendocrine carcinomas in a background of adenoma or adenocarcinoma

\begin{tabular}{|c|c|c|c|c|c|}
\hline Authors & Paper Title & $\begin{array}{l}\text { Date of } \\
\text { Publication }\end{array}$ & Tumor Types & Location & Treatment and Outcome \\
\hline Vilor et al. (22) & $\begin{array}{l}\text { Small cell neuroendocrine } \\
\text { carcinoma of the rectum }\end{array}$ & 1995 & $\begin{array}{l}\text { SCNEC + well-differentiated } \\
\text { papillary AC within villous } \\
\text { adenoma }\end{array}$ & Rectum & $\begin{array}{l}\text { Massive liver metastasis at time } \\
\text { of diagnosis } \\
\text { Survival less than one month }\end{array}$ \\
\hline $\begin{array}{l}\text { Yoshikane } \\
\text { et al. (10) }\end{array}$ & $\begin{array}{l}\text { Small Neuroendocrine } \\
\text { Carcinoma of the Rectum } \\
\text { Entirely Covered by an } \\
\text { Adenomatous Component }\end{array}$ & 2001 & $\begin{array}{l}\text { NEC }(1 \mathrm{~cm})+\text { tubulovillous } \\
\text { adenoma }(5 \mathrm{~cm})\end{array}$ & Rectum & $\begin{array}{l}\text { Tumor found on autopsy of } \\
\text { patient with multiple liver and } \\
\text { bone metastases }\end{array}$ \\
\hline $\begin{array}{l}\text { Mukhopadhyay } \\
\text { et al. (23) }\end{array}$ & $\begin{array}{l}\text { Small Advanced Neuroendocrine } \\
\text { Carcinoma of Rectum Discovered } \\
\text { in an Adenomatous Polyp }\end{array}$ & 2005 & $\begin{array}{l}\text { NEC }(3 \mathrm{~mm})+\text { tubulovillous } \\
\text { adenoma }(9 \mathrm{~mm})\end{array}$ & Rectum & $\begin{array}{l}\text { Liver metastasis at time of diagnosis } \\
\text { Patient declined therapyand was } \\
\text { discharged to hospice }\end{array}$ \\
\hline $\begin{array}{l}\text { Kuratate } \\
\text { et al. (24) }\end{array}$ & $\begin{array}{l}\text { Coexistent poorly-differentiated } \\
\text { neuroendocrine cell carcinoma } \\
\text { and non-invasive well-differentiated } \\
\text { adenocarcinoma in tubulovillous } \\
\text { adenoma of the rectum: report of } \\
\text { a case }\end{array}$ & 2010 & $\begin{array}{l}\text { SCNEC + well- differentiated } \\
\text { AC }(10.5 \mathrm{~cm})\end{array}$ & Rectum & $\begin{array}{l}\text { Liver metastasis at time of diagnosis } \\
\text { Low anterior resection + adjuvant } \\
\text { chemotherapy (FOLFOX and } \\
\text { bevacizumab) } \\
\text { Length of Survival } 3 \text { months }\end{array}$ \\
\hline Sunose et al. (25) & $\begin{array}{l}\text { Large cell neuroendocrine carcinoma } \\
\text { of the ampulla of vater with } \\
\text { adenocarcinoma and squamous cell } \\
\text { carcinoma components }\end{array}$ & 2011 & $\begin{array}{l}\text { LCNEC + well-differentiated } \\
\text { papillary AC + squamous } \\
\text { cell carcinoma }\end{array}$ & $\begin{array}{l}\text { Ampulla } \\
\text { of Vater }\end{array}$ & $\begin{array}{l}\text { Pancreatoduodenectomy + adjuvant } \\
\text { chemotherapy (cisplatin and irinotecan) } \\
\text { Length of Survival } 13 \text { months }\end{array}$ \\
\hline Koletsa et al. (26) & $\begin{array}{l}\text { Neuroendocrine carcinoma in } \\
\text { adenoma of the sigmoid }\end{array}$ & 2014 & $\begin{array}{l}\text { NEC + tubulovillous } \\
\text { adenoma }(2 \mathrm{~cm} \text { polyp })\end{array}$ & $\begin{array}{l}\text { Sigmoid } \\
\text { colon }\end{array}$ & $\begin{array}{l}\text { Sigmoid colectomy } \\
\text { Alive at } 2 \text { year follow-up }\end{array}$ \\
\hline Li et al. (27) & $\begin{array}{l}\text { Combined neuroendocrine carcinoma } \\
\text { and adenocarcinoma in the stomach: } \\
\text { A case report }\end{array}$ & 2014 & $\begin{array}{l}\text { NEC + moderately- } \\
\text { differentiated AC }(5 \mathrm{~cm})\end{array}$ & Stomach & $\begin{array}{l}\text { Radical total gastrectomy + adjuvant } \\
\text { chemotherapy (FOLFOX) } \\
\text { Alive at } 1 \text { year follow-up }\end{array}$ \\
\hline Zou et al. (28) & $\begin{array}{l}\text { An Intramucosal Large Cell } \\
\text { Neuroendocrine Carcinoma Arising } \\
\text { Within a Tubulovillous Adenoma With } \\
\text { High-Grade Dysplasia of the } \\
\text { Rectosigmoid Colon Treated With } \\
\text { Polypectomy }\end{array}$ & 2016 & $\begin{array}{l}\text { LCNEC }(1 \mathrm{~mm})+\text { tubulovillous } \\
\text { adenoma }(4 \mathrm{~cm})\end{array}$ & $\begin{array}{l}\text { Recto - } \\
\text { sigmoid }\end{array}$ & $\begin{array}{l}\text { Polypectomy } \\
\text { Alive at } 1 \text { year follow-up }\end{array}$ \\
\hline Soliman et al. (7) & $\begin{array}{l}\text { Coexisting tubular adenoma with a } \\
\text { neuroendocrine carcinoma of colon } \\
\text { allowing early surgical intervention } \\
\text { and implicating a shared stem cell } \\
\text { origin }\end{array}$ & 2017 & $\begin{array}{l}\text { NEC }(3 \mathrm{~cm})+\text { tubular } \\
\text { adenoma }(3 \mathrm{~mm})\end{array}$ & $\begin{array}{l}\text { Ascending } \\
\text { colon }\end{array}$ & $\begin{array}{l}\text { Right hemicolectomy + adjuvant } \\
\text { chemotherapy (cisplatin and etoposide) } \\
\text { Length of Survival unknown }\end{array}$ \\
\hline Doi et al. (29) & $\begin{array}{l}\text { A neuroendocrine carcinoma with a } \\
\text { well-differentiated adenocarcinoma } \\
\text { component arising in Barrett's } \\
\text { esophagus: a case report and } \\
\text { literature review }\end{array}$ & 2018 & $\begin{array}{l}\text { NEC + well-differentiated AC } \\
(1 \mathrm{~cm})\end{array}$ & Esophagus & $\begin{array}{l}\text { Proximal Gastrectomy } \\
\text { Alive at } 3 \text { year follow-up }\end{array}$ \\
\hline
\end{tabular}

incidences are case reports (table 1). There are several theories that attempt to explain the pathogenesis of colorectal tumors with concurrent neuroendocrine and adenomatous pathology:

1) Mixed tumors are a neuroendocrine phenotype of dedifferentiated adenocarcinoma (11);

2) These tumors originate from a common multipotent stem cell, then simultaneously differentiate into glandular or neuroendocrine lineages (7); or

3) A common genetic alteration predisposes an individual to the development of both tumor types (8).

With an agreed upon pathogenesis, the treatment modality of these tumors may be better elucidated. The two hypotheses that seem to have the most validity are the dedifferentiation and stem cell theories.

The dedifferentiation theory surmises that the neuroendocrine component of the tumor is further along the pathway of cell regression than the adenomatous component. Dedifferentiation is a biological phenomenon in which cells regress from a specialized function to a simpler state (18). The crux of the argument for dedifferentiation is that poorly differentiated areas of colorectal AC can also stain positively for synaptophysin. In 20 cases of colorectal AC with high-grade poorly-differentiated cell clusters, Gurzu et al. reported that all AC expressed synaptophysin, but were negative for chromogranin (12). 
Further supporting this hypothesis, CD133 expression, a marker of cancer stem cells, has been found in varying amounts within different $\mathrm{Gl}$ malignancies; including NET, NEC, AC, and in mixed adenoneuroendocrine carcinoma (MANEC) (13). MANEC tumors, recently characterized by the WHO in 2010, are composite neoplasms containing areas of adenocarcinoma or squamous cell carcinoma integrated with NEC or NET (with each component forming at least $30 \%$ of the neoplasm). When comparing the proportion of neoplasms with CD133 positivity, MANEC and $A C$ were found to have the highest expression ( $64 \%$ and $47 \%$ of tumors, respectively), whereas NET and NEC less frequently expressed CD113 (30\% and 26\%, respectively) (13). From this data, it can be deduced that the neuroendocrine component of mixed tumors is likely a dedifferentiated area of AC with altered phenotype.

On the other hand, several interesting case reports of colorectal collision tumors help support the stem cell theory. A collision tumor consists of two neoplasms in close connection with one another, but are not admixed, and each component is suspected to have its own origin (11). Two cases detail colonic AC and NEC collision tumors that metastasized to lymph nodes as mixed glandular and neuroendocrine neoplasms $(14,15)$. Another case describes a collision tumor in the transverse colon that was removed and subsequently presented 3 years later as a retroperitoneal metastasis with equal parts NEC and AC (7). Together, these help to refute a double primary malignancy theory in favor of a common stem cell precursor.

It seems more evidence supports the hypothesis in which multipotent stem cells display bidirectional differentiation into AC and NEC neoplasms. A study by Kim et al. regarding genome wide loss of heterozygosity $(\mathrm{LOH})$ of eight mixed glandular-neuroendocrine gastric carcinomas showed that one combined tumor (intermixed components), and 5 neuroendocrine-dominant carcinomas shared a primary $\mathrm{LOH}(16)$. $\mathrm{LOH}$ refers to a genetic mutation in which one copy of a normal gene is lost. This frequently leads to the development of cancer, especially if the gene lost is a tumor suppressor. When NEC and an adenoma or AC share identical LOH mutations, it points to their development and differentiation from a common stem cell. In a study of combined tumor genetics, Huang et al. report that a NEC and a tubulovillous adenoma not only shared multiple $\mathrm{LOH}$ mutations at identical chromosomal loci, but also had k-ras mutations (17). Vortmeyer et al. studied LOH mutations of APC, DCC, and p53 genes in 2 cases of pure NEC and 7 cases of NEC associated with colonic adenoma or $\mathrm{AC}$, and report similar findings among the two cell types. Additionally, when there was retention of heterozygosity in the APC gene of one neoplastic component, it was retained in the other as well (18). Therefore, it seems NEC and AC develop from a common precursor stem cell, at which point different carcinogenic factors influence the phenotype of each neoplasm.

Additional support of the stem cell theory comes from the fact that MANEC neoplasms contain amphicrine cells. Amphicrine cells are of endodermal origin, have been found in regular and dysplastic tissues, and have been shown to contain both neuroendocrine secretory granules and mucin droplets (19). Amphicrine carcinomas of the stomach have been shown to be of multivalent stem cell origin. A recent case report confirmed the first amphicrine carcinoma of the small bowel, further supporting the presence of gastrointestinal multipotent stem cells (20). Amphicrine cells have been identified in both components of MANEC tumors (19). This reveals a close genetic relationship between NEC and $\mathrm{AC}$, and a plausible development from a stem cell precursor. As more data regarding these tumors is accrued, whichever hypothesis is validated will lead to better treatment and management of these aggressive neoplasms.

\section{CONCLUSION}

When rare pathology is encountered, a review of the current literature can be helpful to guideline clinical decision making. Our patient presented after incomplete endoscopic excision of a tubulovillous adenoma with high-grade dysplasia in the transverse colon. On final pathology after segmental resection, he was found to have two $5 \mathrm{~mm}$ foci of LCNEC arising from the adenoma, with lymph node metastasis ( 1 of 8 lymph nodes). This unexpected pathology motivated the surgeon to re-resect to negative proximal and distal margins, and harvest additional lymph nodes, all of which were negative for tumor metastasis. This case stresses the importance of careful preoperative planning for a presumed pre-malignant mass, inclusive of tumor markers, staging CT, and formal oncologic resection. If the patient had undergone an oncologic resection during the index operation, any surprises on final pathology would have been appropriately treated in a multidisciplinary fashion without further delay in initiating definitive adjuvant therapy. Despite this, our patient was able to complete 5 of 6 cycles of adjuvant platinum-based chemotherapy and remains diseasefree one year after his diagnosis of LCNEC of the colon. His surveillance involves close clinical follow-up, 
including history and physical exam every 3-6 months, annual CT imaging, and serum chromogranin A levels for the first 3 years and annually thereafter. His one-year post-operative surveillance colonoscopy was unremarkable.

More work is needed to delineate the true pathogenesis of colorectal tumors with concurrent neuroendocrine and adenomatous pathology. There are no agreed-upon management guidelines for colorectal NEC, although given its highly aggressive nature, standard oncologic resection and adjuvant chemotherapy are generally recommended for patients with resectable disease.

\section{Conflicts of Interest}

None Declared. There are no conflicts of interest to declare for all contributing authors.

\section{Author Contribution}

All listed authors have participated sufficiently to this study. Those listed have met all criteria to qualify as contributing authors.

\section{REFERENCES}

1. Klimstra DS. Pathologic Classification of Neuroendocrine Neoplasms. Hematol Oncol Clin North Am. 2016;30(1):1-19.

2. Yao JC, Hassan M, Phan A, Dagohoy C, Leary C, Mares JE, et al. One hundred years after "carcinoid": epidemiology of and prognostic factors for neuroendocrine tumors in 35,825 cases in the United States. J Clin Oncol. 2008;26:3063-3072.

3. Bernick PE, Klimstra DS, Shia J, Minsky B, Saltz L, Shi W, et al. Neuroendocrine carcinomas of the colon and rectum. Dis Colon Rectum. 2004;47:163-9.

4. Moertel C, et al. Treatment of neuroendocrine carcinomas with combined etoposide and cisplatin: evidence of major therapeutic activity in the anaplastic variants of these neoplasms. Cancer. 1991;68:227-32.

5. Jang Jin Kim, Sung Su Park, Taek-Gu Lee, Ho-Chang Lee, SangJeon Lee. Large Cell Neuroendocrine Carcinoma of the Colon with Carcinomatosis Peritonei. Annals of Coloproctology. 2018; 34(4):222-225.

6. Ilett EE, Langer SW, Olsen IH, Federspiel B, Kjșr A, Knigge U Neuroendocrine carcinomas of the gastroenteropancreatic system: a comprehensive review. Diagnostics (Basel). 2015;5:119-76.

7. Soliman M, Tiwari A, Zhao Q. Coexisting tubular adenoma with a neuroendocrine carcinoma of colon allowing early surgical intervention and implicating a shared stem cell origin. World J Gastroenterol. 2017;23(6):1106-1112.

8. Yo Na Kim, Ho Sung Park, Kyu Yun Jang, Woo Sung Moon, Dong Geun Lee, Ho Lee, Min Ro Lee, Kyung Ryoul Kim. Concurrent Large Cell Neuroendocrine Carcinoma and Adenocarcinoma of the Ascending Colon: A Case Report. J Korean SocColoproctol. 2011; 27(3):157-161.

9. Sun JH, Chao M, Zhang SZ, Zhang GQ, Li B, Wu JJ. Coexistence of small cell neuroendocrine carcinoma and villous adenoma in the ampulla of Vater. World J Gastroenterol. 2008;14:4709-4712.
10. Yoshikane H, Arakawa D, Kawashima H, Sakakibara A, Hidano H, Takahashi H, Yokoi T. Small neuroendocrine carcinoma of the rectum entirely covered by an adenomatous component. Endoscopy. 2001;33:298.

11. Gurzu S, Kadar Z, Bara T, Bara T, Tamasi A, Azamfirei L, Jung I. Mixed adenoneuroendocrine carcinoma of gastrointestinal tract: report of two cases. World J Gastroenterol. 2015;21:1329-1333.

12. Gurzu S, Serester 0 , Jung, I. Possible Neuroendocrine Phenotype of Poorly Differentiated Cell Clusters in Colorectal Carcinoma, as a Prognostic Parameter. Am J SurgPathol. 2014;38(1):143-4.

13. Acosta A, Wiley E. Primary Biliary Mixed Adenoneuroendocrine Carcinoma (MANEC): A Short Review. Arch Pathol Lab Med, 2016; 140:1157-1162.

14. Pecorella I, Memeo L, Ciardi A, Rotterdam H. An unusual case of colonic mixed adenoendocrine carcinoma: collision versus composite tumor. A case report and review of the literature. Ann Diagn Pathol. 2007;11(4):285-90.

15. Meşină C, Vasile I, Ciobanu D, Calotă F, Gruia CL, Streba L, Mogoantă SŞ, Pârvănescu H, Georgescu CV, Tarniță DN. Collision tumor of recto-sigmoidian junction - case presentation. Rom J Morphol Embryol. 2014; 55(2 Suppl):643-7.

16. Kim KM, Kim MJ, Cho BK, Choi SW, Rhyu MG. Genetic evidence for the multi-step progression of mixed glandular-neuroendocrine gastric carcinomas. Virchows Arch. 2002;440(1):85-93.

17. Huang J, Behrens C, Wistuba II, Gazdar AF, Jagirdar J. Clonality of Combined Tumors. Arch Pathol Lab Med. 2002;126(4):437-441.

18. Vortmeyer AO, Lubensky IA, Merino MJ, Wang CY, Pham T, Furth $\mathrm{EE}$, Zhuang Z. Concordance of genetic alterations in poorly differentiated colorectal neuroendocrine carcinomas and associated adenocarcinomas. J Natl Cancer Inst. 1997;89(19): 1448-53.

19. La Rosa S, Marando A, Sessa F, Capella C. Mixed Adenoneuroendocrine Carcinomas (MANECs) of the Gastrointestinal Tract: An Update. Cancers (Basel). 2012;4(1):11-30.

20. Ethan L, Shannon M, Diana C, Kathryn P, Cynthia G, Xuefeng Z. Mixed Adenoneuroendocrine Carcinoma, Amphicrine Type, of the Small Bowel. Am J ClinPathol. 2016;145(5):703-709.

21. Lewin K. Carcinoid tumors and the mixed (composite) glandularendocrine cell carcinomas. Am J SurgPathol. 1987;11(suppl 1): 71-86.

22. Vilor M, Tsutsumi Y, Osamura RY, Tokunaga N, Soeda J, Ohta M, Nakazaki H, Shibayama Y, Ueno F. Small cell neuroendocrine carcinoma of the rectum. Pathol Int. 1995;45(8):605-9.

23. Mukhopadhyay S, Marhaba A, Sidhu JS. Small Advanced Neuroendocrine Carcinoma of Rectum Discovered in an Adenomatous Polyp. Endoscopy. 2005;37(12):1256-7.

24. Kuratate S, Inoue S, Chikakiyo M, Kaneda Y, Harino Y, Hirose T, et al. Coexistent poorly-differentiated neuroendocrine cell carcinoma and non-invasive well-differentiated adenocarcinoma in tubulovillous adenoma of the rectum: report of a case. J Med Invest. 2010;57(34):338-44.

25. Sunose $\mathrm{Y}$, Ogawa $\mathrm{T}$, Itoh $\mathrm{H}$, Andoh $\mathrm{T}$, Tomizawa N, Tanaka $\mathrm{T}$, et al. Large Cell Neuroendocrine Carcinoma of the Ampulla of Vater with Adenocarcinoma and Squamous Cell Carcinoma Components. Jpn J ClinOnc. 2011;41(3):434-439.

26. Koletsa T, Beretouli E, Tziola T, Mavropoulou S, Karayannopoulou G. Neuroendocrine carcinoma in adenoma of the sigmoid. Hippokratia. 2014;18(4):362-363.

27. Li S, Cao X, Jiang C, Wang Q. Combined neuroendocrine carcinoma and adenocarcinoma in the stomach: A case report. Oncol Lett. 2014:7(4):953-955.

28. Zou Y, Shi H, Costedio M, \& Liu X. An Intramucosal Large Cell Neuroendocrine Carcinoma Arising Within a Tubulovillous Adenoma With High-Grade Dysplasia of the Rectosigmoid Colon Treated With Polypectomy. Journal Of Medical Cases. 2016;7(5):174-177.

29. Doi S, Matsumoto S, Wakatsuki K, Migita K, Ito M, Kunishige T, et al. A neuroendocrine carcinoma with a well-differentiated adenocarcinoma component arising in Barrett's esophagus: a case report and literature review. Surg Case Rep. 2018;4(1):103. 